\title{
Synergistic Effects of inoculating Arbuscular Mycorrhizal Fungi and Foliar Iron Fertilizer on Broad Bean Growth and Yield Under North Sinai Conditions
}

\author{
Ahmed B. El-Mansy ${ }^{1 *}$, Mohamed A. I. Mansour ${ }^{2}$ and Mahmoud I.M. Ibrahim ${ }^{1}$ \\ ${ }^{1}$ Plant Production Dept., Faculty of Environmental Agricultural Science, Arish University, Al-Arish, P.O. Box 45511, North Sinai, \\ Egypt \\ ${ }^{2}$ Botany and Microbiology Dept., Faculty of Science, Arish University, Al-Arish, P.O. Box 45511, North Sinai, Egypt
}

\begin{abstract}
This work has been done at the Experimental Farm of Fac. Environ. Agric. Sci., Arish University, North Sinai, Egypt. The experiment was run for two successive growing winter seasons during 2016-2018. The synergistic effects of Arbuscular mycorrhizal fungi (AMF) inoculation and foliar iron fertilizer on plant growth and yield parameters of broad bean plant (Vicia faba L.), grown in sandy loam soil, were conducted. Mycorrhizal colonization and their spore intensity, nodule formation and their number were also investigated. Two mycorrhizal treatments (Inoculum AMF and native AMF) and five foliar Fe-concentrations $(0.0,300$, 400, 500 and $600 \mathrm{ppm}$ ) were applied. The interaction between different categories of AMF and foliar Fefertilization was also evaluated. The results obtained revealed that the application of inoculated AMF and spray with $\mathrm{Fe}$ at $400 \mathrm{ppm}$ increased spore count and root colonization. However, total number of active nodules/plant increased with inoculated AMF and spraying iron at $600 \mathrm{ppm}$. Results indicated the superiority interaction treatment of inoculated AMF with the foliar Fe at the concentration of $400 \mathrm{ppm}$ and/or $500 \mathrm{ppm}$ by which it recorded the highest values of plant growth traits; viz, root length, number of branches/plant, total dry weight/plant and photosynthetic pigments content in both seasons. Moreover, the same treatment recorded the highest values with all pod characters and yield, except weight of number of green seeds/pod in first season and average pod weight $(\mathrm{g})$ in the second one.

Keywords: Arbuscular Mycorrhizal Fungi (AMF), Broad bean, foliar iron, Plant growth and Yield
\end{abstract}

\section{INTRODUCTION}

Egypt is located in arid and semi-arid region. The total area of arable land is $3 \times 10^{10} \mathrm{~m}^{2}$, which is only $3 \%$ of the total area of Egypt and the rest is desert. Agricultural land in Egypt is considered one of the world's most intensive agricultural systems (Gheda and Ahmed, 2015; Salama et al., 2017).

Legumes are the major direct source of protein for both human and livestock, especially in poor countries, where animal protein is expensive (Hubbell and Gerald, 2003). Broad bean (Vicia faba L.) is one of these legumes grown as winter vegetable crop in the Mediterranean region and has considerable importance as a low-cost food enriched protein and carbohydrates (Sepetoglu, 2002). It is one of the most important vegetable crops in Egypt. Its seeds contain a high percentage of carbohydrates in addition to mineral elements, fibers, and vitamins (Gao and Shi, 2007). The seeds also contain high percentage of protein ranging between $25-40 \%$ (Natalia et al., 2008) that providing an average of $33 \%$ to $60 \%$ of humans' dietary nitrogen (O'Rourke et al., 2014).

Mycorrhiza is the most widespread symbiotic interactions between microorganism and higher plants (Marschner, 2002; Bonfante and Genre 2008). Arbuscular mycorrhizal fungi (AMF) are obligatorily biotrophic and form mutual symbiosis with about $80 \%$ of vascular plant species in all major terrestrial biomes (Barea and Jeffries, 1995; Feddermann et al., 2010 and Smith et al., 2010). AMF have been reported to have positive influence on plant growth and tolerance to diseases (Pozo et al., 2002; Garmendia et al., 2004 and Wang et al., 2012). AMF can consider as an essential factors for functioning and sustainability of the agro- ecosystem (Abd-Alla et al., 2014 and Nafady et al., 2018). AMF alleviate soil stresses on plant and increased the plant growth and its tolerance (Kumar $e t$ al., 2014). AMF also increased nutrient uptake, accumulation of osmoregulatory compounds, increase in photosynthetic rates, and decrease root respiration and water use (Abdel Latef and Chaoxing, 2011; Porcel $e t$ al., 2012). On the other hand, mycorrhizal fungi develop a network of hyphae that link between the soil, the nutrient reservoir, and the plant roots. This hyphal structure is more efficient for phosphorus and iron absorption than root hairs (Dorneless et al., 2001).

Iron is important element in plant biochemical reactions; it can directly or indirectly improve the growth performance of crops, especially the legumes (Zarghamnejad et al., 2015). Many of metabolic pathways and enzymes are activated by iron that plays an important role in plant growth by stimulating cell division (Rout and Sahoo, 2015). Therefore, iron is considered as a necessary element for the most crops, in particularly legumes since it participates in atmospheric nitrogen fixation process. Moreover, iron has several important functions for plant growth and productivity, including photosynthesis and respiration processes and chlorophyll synthesis which they are functional tools for plant productivity and yield (Houimli et al., 2015; Ferhi et al., 2017; Mann et al., 2017 and Ren et al., 2017). Since iron is impaired in alkaline soil due to the presence of $\mathrm{CaCO}_{3}$, foliar-Fe fertilizer is highly recommended.

Microelements applied in foliar were much more useful than direct applied in soil where in alkaline soil it considered unavailable form (Heidarian et al., 2011). Iron as foliar spraying used as chemical fertilizer for different crops, reduce the effects of salinity, adjusts

*Corresponding author e-mail: aelmansy@Aru.edu.eg 
the soil $\mathrm{pH}$, ameliorate the negative effect of salt stress on the growth and production, increasing plant growth, and yield and its quality (El-Mansi et al., 2005; Tantawy et al., 2013; Al Janabi, 2016 and Houimli et $a l .$, 2016). The main objective of the current work was to study the synergistic effect of inoculation AMF and foliar iron concentrations on the growth characters, yield and its components of broad bean crop using drip irrigation system under North Sinai conditions.

\section{MATERIALS AND METHODS}

\section{Study location and physico-chemical properties of soil and irrigated water used}

The study was conducted at Experimental Farm of the Environmental Agricultural Sciences Faculty, Arish University, North Sinai Governorate, Egypt. The experiment was run for two consecutive winter seasons of 2016/2017 and 2017/2018. The physico-chemical properties of soil and irrigated water were analyzed following the method of Piper (1947) and Jackson (1958). The physico-chemical properties were recorded in average of the two working seasons (Tables 1 and 2).

\section{Experimental design}

To evaluate the effect of AMF or/and foliar iron fertilizer on plant growth and in sequence its yield, a randomized complete block design, with three replica in split design system, was applied. Ten treatments, in which inoculation with propagated AMF verses native occurring AMF (native AMF), spraying with Fe-foliar fertilizer with five different concentrations $(0.00,300$, 400,500 , and $600 \mathrm{ppm}$ ) and the interaction between the two major factors were established.

Treated Vicia faba seedlings with AMF (factor A) were randomly settled in the main plots, meanwhile spraying with foliar-iron fertilizer (factor B) were randomly arranged in the sub plots. Seeds of broad bean cv."Luzde otono" imported from Fito Semillas Co., Turkey, were sown on $1^{\text {st }}$ November in both season around emitters of two dripper lines in hills at $30 \mathrm{~cm}$ between each two hills (the experimental unite was $8 \mathrm{~m}$ length and $0.9 \mathrm{~m}$ wide). Total plot area was $14.40 \mathrm{~m}^{2}$. The area around one dripper line $\left(7.2 \mathrm{~m}^{2}\right)$ was used to estimate growth parameters and the other area was used for estimating yield.

\section{Isolation, purification and identification of AMF from different plants}

AMF spores were collected and isolated from the rhizosphere of several vegetable plants, cultivated in the experimental farm, located at Faculty of Environ. Agric. Sci., Arish Univ., including tomatoes, pepper, eggplant and cucumber plants. Rhizosphere soil samples $(100 \mathrm{~g})$ of each plant were collected by wet sieving and decanting through a series of wire meshes, having a mesh size of $355-25 \mu \mathrm{m}$ sieves (Gerdemann and Nicolson, 1963). The sieved soil samples were centrifuged at $1000 \mathrm{rpm}$ for $15 \mathrm{~min}$ following the method modified from INVAM (2020). To facilitate rapid determination of spore density, spore suspensions were filtered through $7 \mathrm{~cm}$ diameter filter paper Whitman No 1, marked with small squares $(1: 1 \mathrm{~cm})$ to examine spores. For AMF identification, spores were stained with Meltzer's reagent and then examined microscopically, using differential interference contrast microscope, to screen the different morphological properties based on spore shape, color, longest dimension, wall thickness, and hyphal existence and morphology. The diversity of AMF spores was recorded after mounted in poly-vinyl alcohol-lactic acid-glycerol (PVLG) to make permanent slides (Gerdemann and Trappe, 1974; INVAM, 2020).

\section{Trap culture and inoculation technique of AMF}

To increase the AMF propagules, maize (Zea mays L.) was used, as a recommended trap plant, in an autoclaved soil for a period of 4 months to increase spore density. Spores were surface sterilized as described by Ravolanirina et al. (1987). Heavily colonized adventitious roots developed were chopped into small fragments and mixed thoroughly with the associated rhizosphere soil. The examined inoculum was containing roots as hyphae, vesicles, arbuscules and spores. AMF inoculum was added, after standardized at the rate of $50 \mathrm{~g}$ of inoculum, which contains spores and colonized maize root fragments. Inoculum was applied to the experimental field soil and at a depth of $2-3 \mathrm{~cm}$ below broad bean seedlings following the method described by Menge and Timmer (1982).

Table (1): The physical and chemical properties of the experimental soil (average of two seasons).

\begin{tabular}{lc}
\hline \hline Property & Average of two seasons (2016-2018) \\
\hline Physical properties & \\
$\quad$ Texture & Sandy loam \\
Chemical properties & \\
pH & 7.8 \\
EC $\left(\mathbf{d S m}^{-1}\right)$ & 1.3 \\
Total $\mathbf{~}(\mathbf{p p m})$ & 16.22 \\
Total P(ppm) & 0.33 \\
Total K $(\mathbf{p p m})$ & 0.79 \\
\hline \hline
\end{tabular}

* Soil sample was taken at $25 \mathrm{~cm}$ from the soil surface. 
Table (2): Initial chemical analyses of irrigation water (average of two seasons).

\begin{tabular}{|c|c|c|c|c|c|c|c|c|c|}
\hline \multirow{3}{*}{ pH } & \multirow{3}{*}{$\begin{array}{c}\mathbf{E C} \\
(\mathrm{ppm})\end{array}$} & \multicolumn{8}{|c|}{ Soluble ions $\left(\right.$ meq. $\left.I^{-1}\right)$} \\
\hline & & \multicolumn{5}{|c|}{ Cations } & \multicolumn{3}{|c|}{ Anions } \\
\hline & & $\mathrm{Mg}^{-1}$ & $\mathbf{C a}^{++}$ & $\mathrm{Mg}^{++}$ & $\mathrm{Na}^{+}$ & $\mathbf{K}^{+}$ & $\mathrm{Cl}^{-}$ & $\mathrm{HCO}_{3}^{-}$ & $\mathrm{SO}_{4}^{-}$ \\
\hline 7.3 & 3513 & 4499 & 16.33 & 17.6 & 35.87 & 0.27 & 42.26 & 6.13 & 21.41 \\
\hline
\end{tabular}

\section{Determination of AMF colonization}

Mycorrhizal root colonization was evaluated by collecting root samples from experimental plants. The roots were divided into $1-2 \mathrm{~cm}$ segments after being cleaned, hydrolysed in $10 \% \mathrm{KOH}$ solution, neutralized using $10 \% \mathrm{HCl}$ and then stained with $0.05 \%$ glyceroltrypan blue solution for observation of AMF rootcolonization following the method of McGonigle et al. (1990). A hundred stained root samples were randomly selected and observed under a light microscope to determine the intensity of the AMF colonization (Trouvelot et al., 1986). The percentage of AMF colonization in root was calculated by the gridline intersects method of Giovannetti and Mosse (1980) according to the following equation:

AMF colonization $(\%)=$

$$
\frac{\text { Total number of root segments colonized }}{\text { Total number of root segments studied }} \times 100
$$

Root colonization was estimated at different time period of the experiment. Meanwhile, number of spores/100 g soil was also estimated at different interval of 30 days after sowing, flowering, and yield stages, respectively for two successive seasons.

\section{Isolation and inoculation of Rhizobium legumino- sarum inoculant}

Rhizobium sp. used for broad bean inoculation was isolated from fresh surface-sterilized nodules collected from broad bean roots that previously cultivated in the farm of vegetables and crops, Faculty of Environ. Agric. Sci., Arish Univ. To select the compatible native Rhizobium strain, a side trail was established in which Vicia faba seedlings were inoculated with different isolated Rhizobium cultures. The isolate, that showed higher effectivity for $V$. faba seedlings, was selected to precede the study. For inoculum preparation, the selected Rhizobium sp. was propagated on yeast mannitol agar medium (Somasegaran and Hoben, 1985). After $3-5$ days of incubation at $28^{\circ} \mathrm{C}$, the growing Rhizobium was suspended in sterilized saline solution $(0.8 \%)$ and diluted to reach $1 \times 10^{8} \mathrm{CFU} / \mathrm{ml}^{-1}$. The seeds of broad bean were soaked in this suspension for $30 \mathrm{~min}$. and then mixed with a sterilized carrier mixture, consists of peat and vermiculite, to be ready for field cultivation.

\section{Determination of Rhizobium-inoculum efficiency}

Efficiency of Rhizobium-inoculum was determined by counting the total number of Nodules developed per plant, number of active Nodules verses to non-active nodules/ plant. This was done by randomly collecting three root samples, per treatment, at 30 and 45 days after planting for the two seasons. Each plant was washed by water to remove all the soil particles attached to the roots to enhance visualization of nodules. (Ngakou et al., 2009).

\section{Foliar iron application}

In this study, Van Iperen Oligo Standard IronEDDHA 6\% was used as foliar-iron fertilizer. This type was selected for its high purity with a high percentage of ortho-ortho that dissolves rapidly and completely. The fertilizer doses applied were 0.0, 300, 400,500 , and $600 \mathrm{ppm}$. The fertilizer was sprayed once every 21 days and started at day 30 of sowing. Distilled water was used as a dose 0.0 (control treatment).

\section{Plant growth parameters}

Samples of three plants from each experimental unit were randomly taken at 90 days after sowing and the following data, in mean, were recorded for each treatment: a. Stem length, root length and number of both branches and leaves/ plant; b. Total fresh and dry weight/plant.

\section{Measurement of leaf chlorophyll content}

Since chlorophyll (Chl) is an important photosynthetic pigment to the plant that principally determining photosynthetic capacity and in sequence the plant growth, therefore, $\mathrm{Chl} \mathrm{a}$ and $\mathrm{Chl} \mathrm{b}$ were measured for each experimental treatment. Ten-disc samples of the fourth upper leaf of each plant tip were randomly taken, from each experimental unit at 90 days from sowing, followed by acetone extraction and measured spectrophotometry (Wettestein, 1957).

\section{Yield performance under different treatments}

To evaluate the different experimental treatments, mature green pods were harvested at proper maturity stage and then counted and weighed for each experimental unit. Meanwhile, number of pods/plant, pod length, number of green seeds/pod, weight of green seeds/pod, and average pod weight $(\mathrm{g})$ were measured. Yield (ton /faddan) of each treatment was also calculated.

\section{Statistical analysis}

Statistical analysis of the obtained data were performed according to statistical analysis of variance (Snedecor and Cochran (1980). Duncan's multiple range tests was applied for comparison among means (Duncan, 1958).

\section{RESULTS}

\section{Isolation, purification and identification of $\mathrm{AMF}$}

Data obtained from roots and soil rhizosphere of different treatments at the Experimental Farm of Vegetables, Faculty of Environ. Agric. Sci., Arish University, revealed the existence of three genera of AMF (native AMF). The genera represented by 4 
species coexist with various crops (cucumber, eggplant, pepper and tomato) at four different locations (Table 3). According to the frequency of occurrence, the most dominant species were belonging to different taxa that came in the sequence order: the most abundant genus was Funneliformis mosseae (Nicolson and Gerd.) Walker \& Schüßler - Synonym: Glomus mosseae (Nicol. \& Gerd.) Gerd. and Trappe (50.0\%), followed by Rhizophagus clarus (Nicolson and Schenck) Walker and Schüßler, Synonym: Glomus clarum Nicolson and Schenck (20.0\%), Gigaspora margarita Becker and Hall (18.0\%) and Acaulospora laevis Gerd and Trappe (12.0\%).

\section{Increasing soil AMF by trapping culture}

The inoculum potential of AMF in soil as spores has been increased by growing maize to increase spore density. The two elements related to the inoculum potential of AMF namely; spore density (as count/100 g) and root colonization rate were used. Data present in table 3 indicated that average spore counts were 20.75 spores/100 g dry soil and $13.00 \%$ average of root colonization. This result is considered very low because these soils are classified as arid and semi-arid reflecting very poor nutrients. After four months from using maize plant, the spore counts reached 192 spores/100 g dry soil and $76.00 \%$ of root colonization.

\section{Effect of AMF inoculum and foliar-Fe concen- trations and their interaction on spore counts and total root colonization (\%) of Vicia faba plant}

Spore counts and root colonization (\%) in the soil under investigation showed great variability with inoculum AMF verses native AMF alone and with different concentrations of foliar-Fe application. Samples taken at three stages (30 days after sowing, flowering and yield stages) revealed higher significant differences $(p \leq 0.05)$ in spore count and total root colonization $(\%)$ recorded in $2^{\text {nd }}$ season than those recorded in $1^{\text {st }}$ season for all investigated stages (Table 4).

Inoculation with AMF verses native AMF showed significant $(p \leq 0.05)$ increase in spore numbers and the percentage of root colonization at all stages during plant growth for the studied seasons (Table 4). At yield stage, significant $(p \leq 0.05)$ increase was highly recorded for the measured parameters. Second season also recorded higher spore density $(353.80 / 100 \mathrm{~g}$ soil verses $409.68 / 100 \mathrm{~g}$ soil for $1^{\text {st }}$ and $2^{\text {nd }}$ season, respectively) and root colonization $(77.55 \%$ and $79.88 \%$ for 1 st and 2nd season, respectively).

For foliar-Fe fertilization, data represented showed significant $(p \leq 0.05)$ increase in AMF spore density as well as root colonization by AMF, at all growth stages, compared to those without fertilization (Table 4). However, foliar-Fe fertilizer at 400ppm recorded high significant differences $(p \leq 0.01)$ compared to the rest of fertilizer doses. At yield stage, spore density, represented in number $/ 100 \mathrm{~g}$ soil, was significantly higher in $2^{\text {nd }}$ season compared to $1^{\text {st }}$ season at the same dose of Fe-fertilizer (253.84 and 315 per $100 \mathrm{~g}$ soil for $1^{\text {st }}$ and $2^{\text {nd }}$ season, respectively). Meanwhile, percentage of root colonization recorded the highest value at flowering stage for both studied seasons (57.70 and 60.92 for $1^{\text {st }}$ and $2^{\text {nd }}$ season, respectively). Fe-fertilizer at dose $500 \mathrm{ppm}$ also recorded high percentage values (56.69 and 59.01 for 1 st and 2nd season, respectively) but significantly less that Fe-fertilizer at $400 \mathrm{ppm}$ (Table 4). In general, spore densities significantly increased as the plant proceed for maturity stages and AMF-root colonization recorded the highest value at flowering stage (Table 4).

For the interaction effect between AMF inoculum and application of foliar-Fe fertilizer, the results indicated that the combination between AMF and different concentrations of foliar-Fe application resulted in a distinctly high number of spores count and total root colonization (\%) compared with native AMF at different concentrations of foliar Fe and control in both seasons. Data in Table 4 also revealed that, soils with inoculated AMF and sprayed with 400 ppm Fe concentration showed the highest number of spores/100g soil at all stages in both seasons 136.7, 380 and $466 \mathrm{~g}$ soil at 30 days after sowing, at flowering and yield stages in $1^{\text {st }}$ season and 166, 421.3 and 578/100g soil in $2^{\text {nd }}$ season at the same stage. The same result was repeated with total root colonization (\%) with 400 ppm foliar-Fe dose, where the highest percentage was $47.63 \%, 85.25 \%$ and $67.33 \%$ at 30 days after sowing, flowering and fruiting stages in $1^{\text {st }}$ season, respectively

Table (3): Native AMF genera associated with cultivated plant species and their spore numbers and root colonization percentage.

\begin{tabular}{|c|c|c|c|c|c|c|c|}
\hline \multirow{2}{*}{ Plant species } & \multirow{2}{*}{ Family } & \multirow{2}{*}{$\begin{array}{c}\text { Species of } \\
\text { AMF genera }\end{array}$} & \multirow{2}{*}{$\begin{array}{c}\text { Spores } \\
\text { count }\end{array}$} & \multirow{2}{*}{$\begin{array}{c}\text { Root } \\
\text { colonization } \\
(\%) \\
\end{array}$} & \multicolumn{3}{|c|}{ Mycorrhizal status } \\
\hline & & & & & Hyphae & Vesicles & Arbuscule \\
\hline $\begin{array}{l}\text { Cucumber } \\
\text { (Cucumis sativus L.) }\end{array}$ & Cucurbitaceae & $\begin{array}{l}F . \text { mosseae } \\
\text { G. margarita } \\
\text { R. clarus }\end{array}$ & 17 & 9.00 & + & + & + \\
\hline $\begin{array}{l}\text { Eggplant } \\
\text { (Solanum melongena } \mathrm{L} .)\end{array}$ & Solanaceae & $\begin{array}{l}\text { F. mosseae } \\
\text { G. margarita } \\
\text { A. laevis }\end{array}$ & 22 & 14.00 & + & + & + \\
\hline $\begin{array}{l}\text { Pepper } \\
\text { (Capsicum anпиит L.) }\end{array}$ & Solanaceae & $\begin{array}{l}\text { F. mosseae } \\
\text { G. margarita }\end{array}$ & 19 & 12.00 & + & + & + \\
\hline $\begin{array}{l}\text { Tomatoes } \\
\text { (Solanum lycopersicum L.) }\end{array}$ & Solanaceae & $\begin{array}{l}\text { G. margarita } \\
\text { R. clarus }\end{array}$ & 25 & 17.00 & + & + & + \\
\hline Average & & & 20.75 & 13.00 & + & + & + \\
\hline
\end{tabular}


Table (4): Effect of AMF inoculum, foliar iron (Fe) concentrations and their interaction on spore counts and total root colonization $(\%)$ at different stages of Vicia faba plant growth.

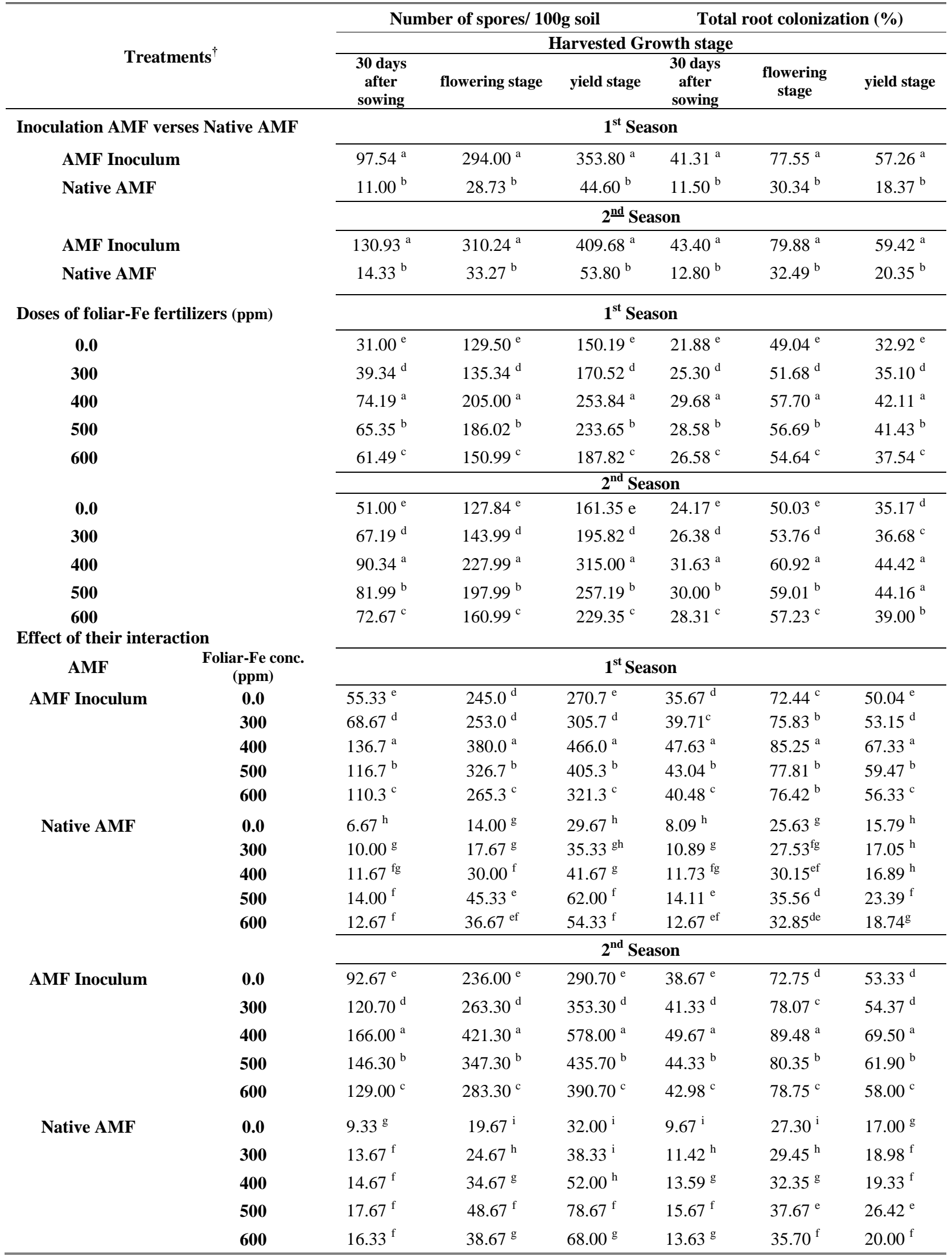

${ }^{\dagger}$ AMF Inoculum, propagated AMF isolated from different plants by trap culture and inoculated to broad bean; Native AMF, AMF exist in soil as native AMF, no inoculation. Values followed by the same letter (s) in a column are not significantly different at $p \leq 0.05$ according to Duncan's multiple range test. 
(Table 4). Recoded results in $2^{\text {nd }}$ season showed nonsignificant increase in total root colonization compared with $1^{\text {st }}$ season $(49.67 \%, 89.48 \%$ and $69.50 \%)$ at the same stages. Contradictory, native AMF treatment and blank foliar-Fe application showed the lowest spore counts and total root colonization (\%) in all growth stages for both seasons $6.67 / 100 \mathrm{~g}$ soil and $8.09 \%$ at 30 days after sowing, $14 / 100 \mathrm{~g}$ soil, $25.63 \%$ at flowering stage and 29.67/100g soil and $15.79 \%$ at yield stage, respectively in $1^{\text {st }}$ season. The data in $2^{\text {nd }}$ season recoded non-significant increments of total root colonization compared to the $1^{\text {st }}$ season $(9.33 / 100 \mathrm{~g}$ soil and $9.67 \%$ at 30 days after sowing, 19.67/100g soil and $27.30 \%$ at flowering stage and $32 / 100 \mathrm{~g}$ soil and $17.00 \%$ at yield stage, respectively, at the same stages.

Effect of AMF inoculum, foliar-Fe concentrations and their interaction on nodules formation on Vicia faba roots

Nodule formation along broad bean was highly influenced by different treatment investigated in this study (Table 5). Inoculation with AMF showed positive effect on nodule formation and a significant, at $p \leq 0.05$ level, increase in their number was recorded. Native AMF recorded less significant nodule counts verses external inoculation with propagated AMF (20.19 and 11.76 for inoculated AMF and native AMF, respectively). At flowering stage of Vicia faba, number of nodules were increased and recorded higher significant values in second season that those in investigated in first season $(37.17,22.21,40.58$ and 25.79 for $A M F$ verses native $A M F$ in $1^{\text {st }}$ and $2^{\text {nd }}$ seasons, respectively).

For foliar-Fe treatment, nodule formation recorded significant $(p \leq 0.05)$ increase as the plants proceed for flowering stage at all foliar-Fe doses applied (Table 5). However, at $600 \mathrm{ppm}$ of foliar-Fe doses exhibited the best concentration for higher nodulation rate for the two successive season periods of the study (35.51 and 39.59 for $1^{\text {st }}$ and $2^{\text {nd }}$ seasons, respectively). The results in $2^{\text {nd }}$ season also increase active nodules/plant 36.06 nodules/plant at the same stages. On the contrary, the number of non-active nodules decreased compared with other foliar Fe concentrations 2.85 nodules/plant in 1 st season while the same result was repeated at all stages in $2^{\text {nd }}$ season.

For AMF and foliar-Fe fertilizers and their influence on nodule formation, table 5 showed synergistic effects where inoculation with propagated AMF and foliar-Fe at $600 \mathrm{ppm}$ recorded the highest significant $(p \leq 0.05)$ nodulation rate and reached its maximum value at flowering stage. Native AMF and foliar-Fe fertilizer at the same dose also recorded significant differences among the other fertilizer doses but less significant compared to applied AMF inoculum. Data recorded for second season also showed higher significant nodulation rate and highest number of nodule developed per plant (34.09 and 47.95 for 30 days after sowing and at flowering stage, respectively). The number of active nodules/ plants at $600 \mathrm{ppm} \mathrm{Fe}$ as foliar spray and inoculated AMF showed the highest value compared with all treatments at the $1^{\text {st }}$ and $2^{\text {nd }}$ season. Wherever, the interaction of control treatment (native AMF with 0.0 foliar $\mathrm{Fe}$ ) gained the highest value of number of non-active nodules 8.01 nodules/plant at flowering stage, in the $1^{\text {st }}$ season. In the $2^{\text {nd }}$ season, the results showed the same effect 10.32 nodules/plant at the same stages. The same behaviour was recorded with native AMF and foliar-Fe fertilizer at $600 \mathrm{ppm}$ (Table 5) and recorded $15.65,29.38,21.14$ and 31.22 at 30 days after sowing and flowering stage for $1^{\text {st }}$ and $2^{\text {nd }}$ seasons, respectively.

\section{Effect of AMF inoculum, foliar-Fe concentrations and their interaction on Vicia faba growth}

Different growth parameters of Vicia faba plant were highly affected by different treatments examined in this study (Table 6). The data reported revealed that inoculated AMF significantly achieved the highest growth parameters in the time period of the study for the two successive seasons. Meanwhile, native AMF recorded the lowest values for all plant growth traits. Data recorded in table 6 also showed that the Foliar-Fe application of at $500 \mathrm{ppm}$ was the superior treat-ment for all measured growth parameters during the two growing seasons except for number of bran-ches/plant in the second season, where Fe fertilizer at $400 \mathrm{ppm}$ recorded the highest values. On the other hand, all plant growth traits were significantly different $(p \leq$ 0.05) than control for both seasons.

It is obvious from the data presented in table 6 that the increments in plant growth characters convolved in stem length, root length; number of both branches and leaves/plant and total of both fresh and dry weight/plant were fluctuated between inoculated AMF in combination with foliar $\mathrm{Fe}$ concentrations of 400 or $500 \mathrm{ppm}$ in both seasons.

Inoculation with $\mathrm{AMF}$ and Fe-fertilizer treatments showed significant synergistic interaction on shoot biomass including stem length, number of leaves/plant and fresh weight/plant in both studied seasons. The interaction treatment (synergistic effects of inoculated AMF and foliar-Fe at $500 \mathrm{ppm}$ ) increased stem length, number of leaves/ plant and fresh weight/plant in both seasons. However, combination between inoculated AMF with foliar Fe at 400 ppm resulting in the highest values of root length and total dry weight / plant in both seasons was obtained. On the other hand, number of branches/ plant gives highest value with using inoculated $\mathrm{AMF}$ and foliar $\mathrm{Fe}$ at $500 \mathrm{ppm}$ in the first season while in the second season inoculated AMF and foliar $\mathrm{Fe}$ at $400 \mathrm{ppm}$ had the highest number of branches/ plant.

\section{Effect of AMF inoculum, foliar-Fe concentrations and their interaction on Leaf chlorophyll a and $b$ content}

Inoculation with AMF along with foliar-Fe concentrations showed significant positive effect on chlorophyll content of the $V$. faba plants verses to those without inoculation (native AMF). Data represented in Figs 1 and 2 showed AMF and 400 ppm are significantly the highest in chlorophyll content ( $\mathrm{Chl} \mathrm{a}$ and $\mathrm{b}$ for $1^{\text {st }}$ and $2^{\text {nd }}$ seasons, respectively). On the other 
Table (5): Effect of AMF inoculum, foliar iron (Fe) concentrations and their interaction on nodule formation at different stages, 30 days of sowing and flowering stages, of Vicia faba plant.

\begin{tabular}{|c|c|c|c|c|c|c|c|}
\hline & & \multirow{2}{*}{\multicolumn{2}{|c|}{$\begin{array}{c}\text { Total number of } \\
\text { nodules/plant }\end{array}$}} & \multicolumn{4}{|c|}{ Nodule activity (Number plant $^{-1}$ ) } \\
\hline & & & & Activ & codule & Non & ctive \\
\hline \multirow{2}{*}{\multicolumn{2}{|c|}{ Treatments $^{\dagger}$}} & \multicolumn{6}{|c|}{ Harvesting Time } \\
\hline & & $\begin{array}{l}30 \text { Days } \\
\text { after } \\
\text { sowing }\end{array}$ & $\begin{array}{c}\text { Flowering } \\
\text { stage }\end{array}$ & $\begin{array}{l}30 \text { Days } \\
\text { after } \\
\text { sowing }\end{array}$ & $\begin{array}{c}\text { Flowering } \\
\text { stage }\end{array}$ & $\begin{array}{l}30 \text { Days } \\
\text { after } \\
\text { sowing }\end{array}$ & $\begin{array}{c}\text { Flowering } \\
\text { stage }\end{array}$ \\
\hline \multirow{2}{*}{\multicolumn{2}{|c|}{$\begin{array}{c}\text { Inoculation AMF verses Native AMF } \\
\text { AMF Inoculum }\end{array}$}} & \multicolumn{6}{|c|}{$1^{\text {st }}$ Season } \\
\hline & & $20.19^{a}$ & $37.04^{\mathrm{a}}$ & $17.30^{\mathrm{a}}$ & $34.16^{\mathrm{a}}$ & $2.89^{\mathrm{b}}$ & $2.88^{\mathrm{b}}$ \\
\hline \multirow{2}{*}{\multicolumn{2}{|c|}{ Native AMF }} & $11.76^{\mathrm{b}}$ & $22.08^{b}$ & $8.61^{\mathrm{b}}$ & $18.13^{\mathrm{b}}$ & $3.15^{\mathrm{a}}$ & $3.95^{\mathrm{a}}$ \\
\hline & & \multicolumn{6}{|c|}{$2^{\text {nd }}$ Season } \\
\hline \multicolumn{2}{|c|}{ AMF Inoculum } & $28.83^{\mathrm{a}}$ & $40.58^{\mathrm{a}}$ & $25.31^{\mathrm{a}}$ & $37.17^{\mathrm{a}}$ & $3.52^{\mathrm{b}}$ & $3.41^{\mathrm{b}}$ \\
\hline \multicolumn{2}{|c|}{ Native AMF } & $16.45^{\mathrm{b}}$ & $25.80^{\mathrm{b}}$ & $12.64^{\mathrm{b}}$ & $20.91^{\mathrm{b}}$ & $3.81^{\mathrm{a}}$ & $4.89^{\mathrm{a}}$ \\
\hline \multicolumn{2}{|c|}{ Doses of foliar-Fe fertilizers (ppm) } & \multicolumn{6}{|c|}{$1^{\text {st }}$ Season } \\
\hline \multicolumn{2}{|r|}{0.0} & $10.95^{\mathrm{e}}$ & $21.06^{\mathrm{e}}$ & $7.53^{\mathrm{e}}$ & $15.61^{\mathrm{c}}$ & $3.42^{\mathrm{a}}$ & $5.45^{\mathrm{a}}$ \\
\hline \multicolumn{2}{|r|}{300} & $13.73^{d}$ & $27.56^{d}$ & $10.73^{d}$ & $24.56^{\mathrm{d}}$ & $3.00^{\mathrm{b}}$ & $3.00^{\mathrm{b}}$ \\
\hline \multicolumn{2}{|r|}{400} & $15.03^{c}$ & $30.28^{c}$ & $12.05^{\mathrm{v}}$ & $27.37^{\mathrm{c}}$ & $2.98^{\mathrm{c}}$ & $2.91^{\mathrm{c}}$ \\
\hline \multicolumn{2}{|c|}{500} & $18.91^{\mathrm{b}}$ & $33.43^{\mathrm{b}}$ & $16.00^{\mathrm{b}}$ & $30.54^{\mathrm{b}}$ & $2.91^{\mathrm{c}}$ & $2.89^{\mathrm{c}}$ \\
\hline \multirow{2}{*}{\multicolumn{2}{|c|}{600}} & $21.25^{\mathrm{a}}$ & $35.51^{\mathrm{a}}$ & $18.47^{\mathrm{a}}$ & $32.66^{\mathrm{a}}$ & $2.78^{\mathrm{c}}$ & $2.85^{\mathrm{c}}$ \\
\hline & & \multicolumn{6}{|c|}{$2^{\text {nd }}$ Season } \\
\hline \multicolumn{2}{|r|}{0.0} & $15.41^{\mathrm{e}}$ & $23.56^{\mathrm{e}}$ & $11.30^{\mathrm{e}}$ & $16.95^{\mathrm{e}}$ & $4.11^{\mathrm{a}}$ & $6.61^{\mathrm{a}}$ \\
\hline \multicolumn{2}{|c|}{300} & $21.45^{\mathrm{d}}$ & $32.00^{\mathrm{d}}$ & $17.89^{d}$ & $28.44^{\mathrm{d}}$ & $3.56^{\mathrm{b}}$ & $3.56^{\mathrm{b}}$ \\
\hline \multicolumn{2}{|r|}{400} & $23.23^{c}$ & $34.00^{c}$ & $19.73^{c}$ & $30.44^{c}$ & $3.50^{\mathrm{b}}$ & $3.56^{\mathrm{b}}$ \\
\hline \multicolumn{2}{|r|}{500} & $25.51^{\mathrm{b}}$ & $36.82^{\mathrm{b}}$ & $21.93^{\mathrm{b}}$ & $33.31^{\mathrm{b}}$ & $3.58^{\mathrm{b}}$ & $3.51^{\mathrm{b}}$ \\
\hline \multicolumn{2}{|r|}{600} & $27.62^{\mathrm{a}}$ & $39.59^{\mathrm{a}}$ & $24.04^{\mathrm{a}}$ & $36.06^{\mathrm{a}}$ & $3.58^{\mathrm{b}}$ & $3.53^{\mathrm{b}}$ \\
\hline Effect of their inte & & & & & & & \\
\hline AMF & Foliar-Fe conc. (ppm) & & & $\mathbf{1}^{\text {st }}$ & ason & & \\
\hline & 0.0 & $14.96^{\mathrm{de}}$ & $31.23^{\mathrm{e}}$ & $12.25^{\mathrm{de}}$ & $28.35^{\mathrm{d}}$ & $2.71^{b}$ & $2.88^{\mathrm{b}}$ \\
\hline & 300 & $17.74^{c}$ & $35.01^{\mathrm{d}}$ & $14.75^{c}$ & $32.16^{c}$ & $2.99^{\mathrm{b}}$ & $2.85^{\mathrm{b}}$ \\
\hline AMF Inoculum & 400 & $18.00^{\mathrm{c}}$ & $37.77^{c}$ & $14.95^{\mathrm{c}}$ & $34.27^{\mathrm{b}}$ & $3.05^{\mathrm{b}}$ & $2.87^{\mathrm{b}}$ \\
\hline & 500 & $23.36^{\mathrm{b}}$ & $40.21^{\mathrm{b}}$ & $20.49^{\mathrm{b}}$ & $37.32^{\mathrm{a}}$ & $2.87^{\mathrm{b}}$ & $2.89^{b}$ \\
\hline & 600 & $26.83^{\mathrm{a}}$ & $41.64^{\mathrm{a}}$ & $24.04^{a}$ & $38.72^{\mathrm{a}}$ & $2.79^{\mathrm{b}}$ & $2.92^{\mathrm{b}}$ \\
\hline & 0.0 & $6.93^{\mathrm{h}}$ & $10.88^{\mathrm{j}}$ & $2.80^{\mathrm{h}}$ & $2.87^{\mathrm{i}}$ & $4.13^{\mathrm{a}}$ & $8.01^{\mathrm{a}}$ \\
\hline & 300 & $9.73^{\mathrm{g}}$ & $20.09 \mathrm{i}$ & $6.72^{\mathrm{g}}$ & $16.95^{\mathrm{h}}$ & $3.01^{\mathrm{b}}$ & $3.14^{\mathrm{b}}$ \\
\hline Native AMF & 400 & $12.06^{\mathrm{f}}$ & $23.40^{\mathrm{h}}$ & $9.14^{\mathrm{f}}$ & $20.46^{\mathrm{g}}$ & $2.92^{\mathrm{b}}$ & $2.94^{\mathrm{b}}$ \\
\hline & 500 & $14.45^{\mathrm{e}}$ & $26.64^{\mathrm{g}}$ & $11.51^{\mathrm{e}}$ & $23.76^{\mathrm{f}}$ & $2.94^{\mathrm{b}}$ & $2.88^{\mathrm{b}}$ \\
\hline & 600 & $15.65^{\mathrm{d}}$ & $29.38^{f}$ & $12.89^{\mathrm{d}}$ & $26.59^{\mathrm{e}}$ & $2.76^{\mathrm{b}}$ & $2.79^{\mathrm{b}}$ \\
\hline & & & & $2^{\text {nd }}$ & ason & & \\
\hline & 0.0 & $23.23^{\mathrm{e}}$ & $33.40^{\mathrm{d}}$ & $19.74^{\mathrm{e}}$ & $30.51^{c}$ & $3.49^{b}$ & $2.89^{b c}$ \\
\hline & 300 & $26.90^{\mathrm{d}}$ & $38.45^{\mathrm{cd}}$ & $23.34^{d}$ & $34.86^{\mathrm{bc}}$ & $3.56^{\mathrm{b}}$ & $3.59^{\mathrm{b}}$ \\
\hline AMF Inoculum & 400 & $28.56^{\mathrm{c}}$ & $39.55^{\mathrm{c}}$ & $25.08^{c}$ & $36.04^{\mathrm{b}}$ & $3.48^{\mathrm{b}}$ & $3.51^{\mathrm{b}}$ \\
\hline & 500 & $31.33^{\mathrm{b}}$ & $43.55^{b}$ & $27.82^{b}$ & $39.99^{\mathrm{a}}$ & $3.51^{\mathrm{b}}$ & $3.56^{\mathrm{b}}$ \\
\hline & 600 & $34.09^{\mathrm{a}}$ & $47.95^{a}$ & $30.55^{\mathrm{a}}$ & $44.44^{\mathrm{a}}$ & $3.54^{\mathrm{b}}$ & $3.51^{\mathrm{b}}$ \\
\hline & 0.0 & $7.57^{\mathrm{h}}$ & $13.70^{\mathrm{i}}$ & $2.85^{\mathrm{i}}$ & $3.38^{\mathrm{g}}$ & $4.72^{\mathrm{a}}$ & $10.32^{\mathrm{a}}$ \\
\hline & 300 & $16.00^{\mathrm{gh}}$ & $25.53^{h}$ & $12.44^{\mathrm{h}}$ & $22.01^{\mathrm{f}}$ & $3.56^{\mathrm{b}}$ & $3.52^{\mathrm{b}}$ \\
\hline Native AMF & 400 & $17.89^{\mathrm{g}}$ & $28.44^{\mathrm{g}}$ & $14.37^{\mathrm{g}}$ & $24.83^{\mathrm{e}}$ & $3.52^{\mathrm{b}}$ & $3.61^{\mathrm{b}}$ \\
\hline & 500 & $19.67^{\mathrm{f}}$ & $30.09^{\mathrm{f}}$ & $16.03^{\mathrm{fg}}$ & $26.63^{\mathrm{de}}$ & $3.64^{\mathrm{b}}$ & $3.46^{\mathrm{b}}$ \\
\hline & 600 & $21.14^{\mathrm{f}}$ & $31.23^{\mathrm{e}}$ & $17.52^{f}$ & $27.68^{d}$ & $3.62^{\mathrm{b}}$ & $3.55^{\mathrm{b}}$ \\
\hline
\end{tabular}

${ }^{\dagger}$ AMF Inoculum, propagated AMF isolated from different plants by trap culture and inoculated to broad bean; Native AMF, AMF exist in soil as native AMF, no inoculation. Means followed by the same letter (s) per column are not significantly different at $p \leq 0.05$ according to Duncan's multiple range test. 
Table (6): Effect of AMF inoculum, foliar iron (Fe) concentrations and their interaction on Vicia faba growth at harvesting time, 90 days after seed sowing.

\begin{tabular}{|c|c|c|c|c|c|c|c|}
\hline \multirow{2}{*}{\multicolumn{2}{|c|}{ Treatments $^{\dagger}$}} & \multicolumn{6}{|c|}{ Plant growth parameters } \\
\hline & & $\begin{array}{l}\text { Stem } \\
\text { length } \\
(\mathrm{cm})\end{array}$ & $\begin{array}{l}\text { Root } \\
\text { length } \\
(\mathrm{cm})\end{array}$ & $\begin{array}{l}\text { Number of } \\
\text { branches/P } \\
\text { lant }\end{array}$ & $\begin{array}{l}\text { Number of } \\
\text { leaves/Plant }\end{array}$ & $\begin{array}{l}\text { Total fresh } \\
\text { weight/Plant } \\
\text { (g) }\end{array}$ & $\begin{array}{l}\text { Total dry } \\
\text { weight/ } \\
\text { plant(g) }\end{array}$ \\
\hline \multicolumn{2}{|c|}{$\begin{array}{l}\text { Inoculation AMF verses Native } \\
\text { AMF }\end{array}$} & \multicolumn{6}{|c|}{$1^{\text {st }}$ Season } \\
\hline \multicolumn{2}{|r|}{ AMF Inoculum } & $95.40^{\mathrm{a}}$ & $38.73^{\mathrm{a}}$ & $9.73^{\mathrm{a}}$ & $113.30^{\mathrm{a}}$ & $800^{a}$ & $215^{\mathrm{a}}$ \\
\hline \multirow{2}{*}{\multicolumn{2}{|c|}{ Native AMF }} & $75.70^{b}$ & $24.56^{\mathrm{b}}$ & $7.07^{\mathrm{b}}$ & $81.20^{\mathrm{b}}$ & $547^{\mathrm{b}}$ & $150^{\mathrm{b}}$ \\
\hline & & \multicolumn{6}{|c|}{$2^{\text {nd }}$ Season } \\
\hline \multicolumn{2}{|r|}{ AMF Inoculum } & $94.00^{\mathrm{a}}$ & $39.93^{\mathrm{a}}$ & $8.73^{\mathrm{a}}$ & $109.33^{\mathrm{a}}$ & $833^{\mathrm{a}}$ & $227^{\mathrm{a}}$ \\
\hline \multicolumn{2}{|r|}{ Native AMF } & $72.10^{b}$ & $23.67^{\mathrm{b}}$ & $6.67^{\mathrm{b}}$ & $79.20^{\mathrm{b}}$ & $576^{\mathrm{b}}$ & $160^{\mathrm{b}}$ \\
\hline \multicolumn{2}{|c|}{ Doses of foliar-Fe fertilizers (ppm) } & \multicolumn{6}{|c|}{ 1st Season } \\
\hline & $\mathbf{0 . 0}$ & $63.67^{\mathrm{e}}$ & $22.50^{\mathrm{e}}$ & $4.50^{\mathrm{e}}$ & $61.67^{\mathrm{e}}$ & $468^{\mathrm{e}}$ & $126^{\mathrm{e}}$ \\
\hline & 300 & $72.67^{\mathrm{d}}$ & $25.50^{\mathrm{d}}$ & $7.50^{\mathrm{d}}$ & $96.17^{\mathrm{c}}$ & $566^{\mathrm{d}}$ & $145^{\mathrm{d}}$ \\
\hline & 400 & $92.17^{\mathrm{c}}$ & $36.00^{b}$ & $10.0^{\mathrm{b}}$ & $121.2^{\mathrm{b}}$ & $754^{\mathrm{b}}$ & $208^{b}$ \\
\hline & 500 & $105.2^{\mathrm{a}}$ & $42.00^{\mathrm{a}}$ & $11.5^{\mathrm{a}}$ & $133.2^{\mathrm{a}}$ & $925^{\mathrm{a}}$ & $249^{a}$ \\
\hline \multicolumn{2}{|r|}{600} & $94.17^{\mathrm{b}}$ & $32.25^{\mathrm{c}}$ & $8.5^{c}$ & $74.17^{\mathrm{d}}$ & $655^{\mathrm{c}}$ & $186^{\mathrm{c}}$ \\
\hline & & \multicolumn{6}{|c|}{$2^{\text {nd }}$ Season } \\
\hline & 0.0 & $63.17^{\mathrm{e}}$ & $22.50^{\mathrm{e}}$ & $5.50^{\mathrm{c}}$ & $59.17^{\mathrm{e}}$ & $492.0^{\mathrm{e}}$ & $127.0^{\mathrm{e}}$ \\
\hline & 300 & $73.17^{\mathrm{d}}$ & $25.50^{\mathrm{d}}$ & $7.50^{\mathrm{b}}$ & $90.67^{\mathrm{c}}$ & $591.0^{\mathrm{d}}$ & $160.0^{\mathrm{d}}$ \\
\hline & 400 & $85.17^{\mathrm{c}}$ & $36.00^{\mathrm{b}}$ & $9.50^{\mathrm{a}}$ & $119.7^{\mathrm{b}}$ & $785.0^{\mathrm{b}}$ & $225.0^{\mathrm{b}}$ \\
\hline & 500 & $101.70^{\mathrm{a}}$ & $42.00^{\mathrm{a}}$ & $9.00^{\mathrm{a}}$ & $131.20^{\mathrm{a}}$ & $963.0^{\mathrm{a}}$ & $263.0^{\mathrm{a}}$ \\
\hline & 600 & $92.17^{\mathrm{b}}$ & $32.25^{c}$ & $7.00^{\mathrm{b}}$ & $70.67^{d}$ & $694.0^{\mathrm{c}}$ & $192.0^{\mathrm{c}}$ \\
\hline \multicolumn{8}{|c|}{ Effect of their interaction } \\
\hline AMF & Foliar-Fe conc. (ppm) & \multicolumn{6}{|c|}{$1^{\text {st }}$ Season } \\
\hline \multirow{5}{*}{$\begin{array}{l}\text { AMF } \\
\text { inoculum }\end{array}$} & $\mathbf{0 . 0}$ & $67.00^{\mathrm{h}}$ & $25.33^{f}$ & $5.33^{\mathrm{e}}$ & $73.33^{f}$ & $511^{\mathrm{g}}$ & $134.6^{\mathrm{g}}$ \\
\hline & 300 & $81.00^{\mathrm{f}}$ & $30.33^{\mathrm{e}}$ & $9.33^{c}$ & $133.30^{\mathrm{b}}$ & $662^{\mathrm{e}}$ & $165.0^{\mathrm{e}}$ \\
\hline & 400 & $111.00^{b}$ & $49.33^{\mathrm{a}}$ & $10.33^{b}$ & $134.30^{b}$ & $964^{\mathrm{b}}$ & $281.0^{\mathrm{a}}$ \\
\hline & 500 & $117.00^{\mathrm{a}}$ & $48.33^{b}$ & $13.33^{\mathrm{a}}$ & $150.30^{\mathrm{a}}$ & $1046^{\mathrm{a}}$ & $267.0^{\mathrm{b}}$ \\
\hline & 600 & $101.00^{c}$ & $40.33^{c}$ & $10.33^{b}$ & $75.33^{e}$ & $817^{\mathrm{c}}$ & $226.0^{d}$ \\
\hline \multirow{6}{*}{$\begin{array}{l}\text { Native } \\
\text { AMF }\end{array}$} & 0.0 & $60.33^{j}$ & $19.67^{j}$ & $3.67^{\mathrm{f}}$ & $50.00^{\mathrm{h}}$ & $424.0^{j}$ & $118.0^{\mathrm{i}}$ \\
\hline & 300 & $64.33^{\mathrm{i}}$ & $20.67^{\mathrm{i}}$ & $5.67^{\mathrm{e}}$ & $59.00^{\mathrm{g}}$ & $470.0 \mathrm{i}$ & $124.0^{\mathrm{h}}$ \\
\hline & 400 & $73.33^{\mathrm{g}}$ & $22.67^{\mathrm{h}}$ & $9.67^{c}$ & $108.00^{\mathrm{d}}$ & $544.0^{f}$ & $135.0^{\mathrm{g}}$ \\
\hline & 500 & $93.33^{\mathrm{d}}$ & $35.67^{\mathrm{d}}$ & $9.67^{\mathrm{c}}$ & $116.00^{c}$ & $805.0^{\mathrm{d}}$ & $230.0^{\mathrm{c}}$ \\
\hline & 600 & $87.33^{\mathrm{e}}$ & $24.17^{\mathrm{g}}$ & $6.67^{\mathrm{d}}$ & $73.00^{f}$ & $492.0^{\mathrm{h}}$ & $145.0^{\mathrm{f}}$ \\
\hline & & \multicolumn{6}{|c|}{$2^{\text {nd }}$ Season } \\
\hline \multirow{5}{*}{$\begin{array}{l}\text { AMF } \\
\text { inoculum }\end{array}$} & 0.0 & $71.00^{\mathrm{g}}$ & $22.33^{\mathrm{d}}$ & $6.33^{\mathrm{e}}$ & $60.33^{\mathrm{g}}$ & $542.0^{\mathrm{g}}$ & $134.0^{\mathrm{h}}$ \\
\hline & 300 & $86.00^{e}$ & $34.33^{c}$ & $8.33^{c}$ & $120.30^{c}$ & $700.0^{\mathrm{e}}$ & $185.0^{\mathrm{e}}$ \\
\hline & 400 & $101.00^{b}$ & $50.33^{a}$ & $11.33^{\mathrm{a}}$ & $140.30^{\mathrm{b}}$ & $1002.0^{\mathrm{b}}$ & $301.0^{\mathrm{a}}$ \\
\hline & 500 & $113.00^{\mathrm{a}}$ & $50.33^{\mathrm{a}}$ & $9.33^{b}$ & $155.30^{\mathrm{a}}$ & $1076.0^{\mathrm{a}}$ & $285.0^{\mathrm{b}}$ \\
\hline & 600 & $99.00^{c}$ & $42.33^{b}$ & $8.33^{c}$ & $70.33^{f}$ & $848.0^{\mathrm{d}}$ & $230.0^{\mathrm{d}}$ \\
\hline \multirow{5}{*}{$\begin{array}{l}\text { Native } \\
\text { AMF }\end{array}$} & 0.0 & $55.33^{\mathrm{j}}$ & $20.67^{f}$ & $4.67^{g}$ & $58.00^{\mathrm{h}}$ & $442.0^{\mathrm{j}}$ & $120.0^{\mathrm{i}}$ \\
\hline & 300 & $60.33^{\mathrm{i}}$ & $19.67^{\mathrm{g}}$ & $6.67^{\mathrm{e}}$ & $61.00^{\mathrm{g}}$ & $483.0^{\mathrm{i}}$ & $135.0^{\mathrm{h}}$ \\
\hline & 400 & $69.33^{h}$ & $21.67^{\mathrm{e}}$ & $7.67^{\mathrm{d}}$ & $99.00^{\mathrm{e}}$ & $567.0^{\mathrm{f}}$ & $150.0^{\mathrm{g}}$ \\
\hline & 500 & $90.33^{d}$ & $34.67^{c}$ & $8.67^{\mathrm{c}}$ & $107.00^{d}$ & $850.0^{c}$ & $241.0^{c}$ \\
\hline & 600 & $85.33^{f}$ & $21.67^{\mathrm{e}}$ & $5.67^{\mathrm{f}}$ & $71.00^{f}$ & $540.0^{\mathrm{h}}$ & $153.0^{\mathrm{f}}$ \\
\hline
\end{tabular}

${ }^{\dagger}$ AMF Inoculum, propagated AMF isolated from different plants by trap culture and inoculated to broad bean; Native AMF, AMF exist in soil as native AMF, no inoculation. Means followed by the same letter (s) per column are not significantly different at $p \leq 0.05$ according to Duncan's multiple range test. 
hand, native AMF recorded the lowest value of chlorophyll content except for fertilization with foliar-Fe at 600 ppm which recorded $5.1 \mathrm{mg} / 100 \mathrm{~g} \mathrm{FW}$ (Fig. 1).

Data in Fig. 2 show that application of foliar-Fe at $500 \mathrm{ppm}$ was the superior treatment on Leaf chlorophyll a and $\mathrm{b}$ content in first season, where it recorded the highest $\mathrm{Chl} \mathrm{a}$ and $\mathrm{b}$ content. While, in the $2^{\text {nd }}$ season $\mathrm{Fe}$ at $400 \mathrm{ppm}$ recorded the highest value. On the other hand, the lowest values for Leaf chlorophyll a and $\mathrm{b}$ content were detected in season with control treatment, no AMF inoculation or foliar-Fe application.

Application of inoculation broad bean plants with $\mathrm{AMF}$ and spray with foliar Fe at a concentration of 400 or 500 ppm showed the promising increased photosy- nthetic pigments content in both seasons without significant differences as shown in Figs. 1 and 2. Meanwhile, synergistic effects of control treatment (native AMF with 0.0 foliar Fe) had the lowest values in both seasons.

Effect of AMF inoculum, foliar-Fe concentrations and their interaction on Vicia faba yield and its components

Table 7 shows that inoculated AMF resulted in increasing all broad bean yields and its components in both seasons of the study, while, the least values were gained by the treatment of native AMF in both seasons. The increase in yield and its components recorded in treatment of inoculation with AMF might be owed
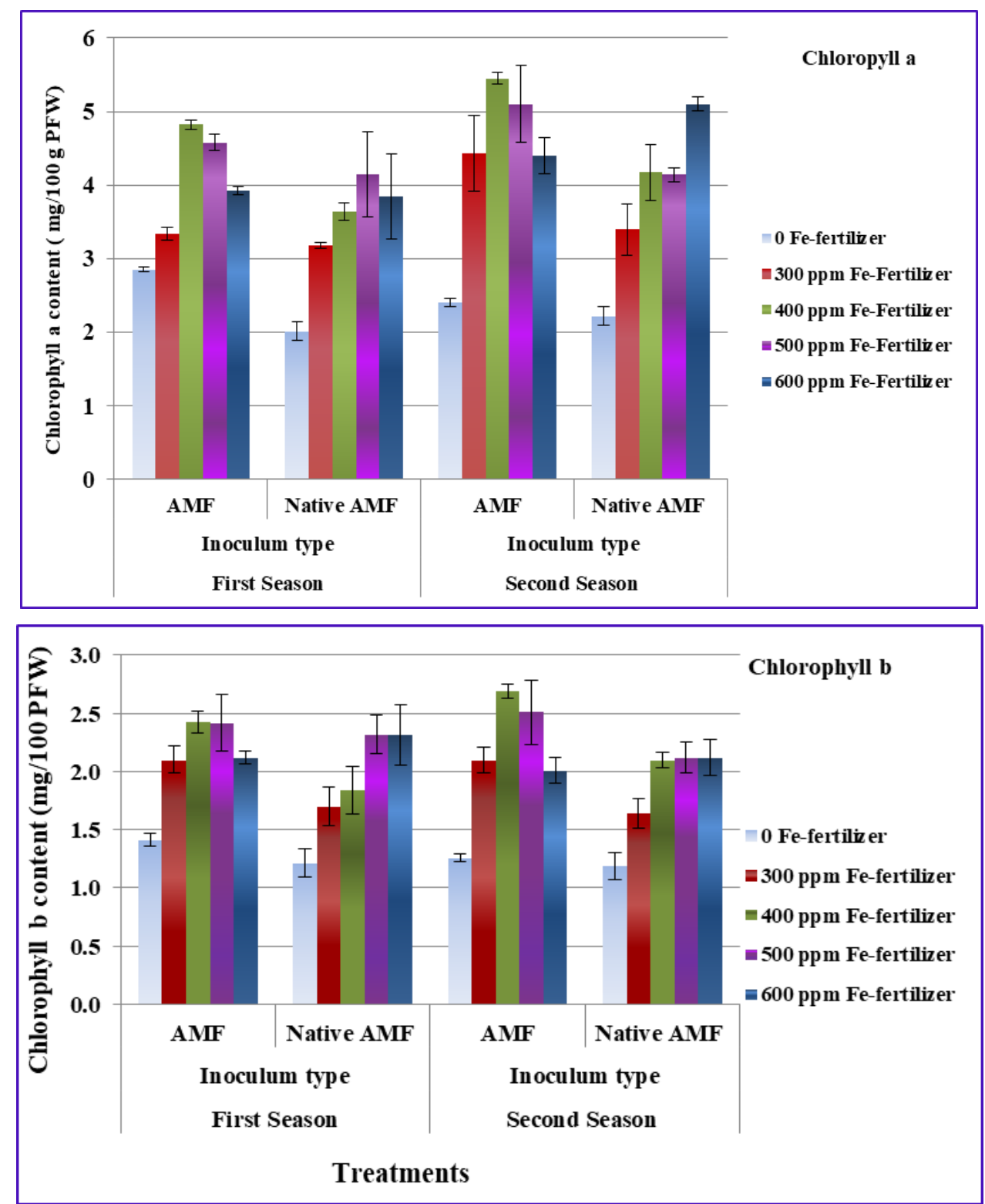

Figures (1) and (2): Effect of AMF inoculum, foliar-Fe fertilizer concentrations and their interaction on chlorophyll a and b content, respectively, of Vicia faba plant at 90 days of sawing. Data are represented in mean \pm SE. 
directly to the increment in nitrogen supply reflecting an increase in plant growth as shown in Table 7.

Obviously, Table 7 showed that the applying foliar$\mathrm{Fe}$ on broad bean plants at $500 \mathrm{ppm}$ significantly increased pod length, number of pods /plant, average pod weight $(\mathrm{g})$ and yield (ton/faddan) in the $1^{\text {st }}$ season. However, the highest values of number of green seeds per pod and weight of green seeds/pod were obtained with $600 \mathrm{ppm}$ of Fe application. In the second season, foliar $\mathrm{Fe}$ at $500 \mathrm{ppm}$ reflected the highest values of weight for green seeds / pod, number of pod / plant, average pod weight and total yield/faddan. However, the highest value for pod length recorded with application of $400 \mathrm{ppm}$ of $\mathrm{Fe}$ and for number of green seeds/pods with using of 300, 500 and $600 \mathrm{ppm}$ of Fe as well.

Meanwhile, the increments in broad bean yield and its components resulted from spraying with $\mathrm{Fe}$ at 500 ppm might be owed to the increase in plant growth as shown in table 7 . The increments in yield and its components might be also owed to the increment in active nodules formation, increasing in photosynthetic pigments, dry weight of plant and therefore increasing in yield.

Inoculation broad bean plants with AMF and spray with foliar-Fe at a concentration of 400 ppm showed the promising treatment in both seasons as shown in table 7. The same previous interaction treatment increased all the components of yield; viz, pod length, number of green seeds/pod, number of pods/ plant, and yield (tons/feddan) in both seasons as well as weight of green seeds/pod in the 2nd one. In addition, inoculated $\mathrm{AMF}$ with foliar $\mathrm{Fe}$ at a concentration of $600 \mathrm{ppm}$ interaction treatment achieved the highest number of green seeds/pod and weight green seeds/pod in the 1st season. Meanwhile, interaction between inoculated AMF with foliar $\mathrm{Fe}$ at a concentration of $500 \mathrm{ppm}$ increased average pod weight in the $2^{\text {nd }}$ season. It could be concluded that the best interaction treatments for yield and its components followed the order at $\mathrm{Fe}$ concentration of $400 \mathrm{ppm}, 600 \mathrm{ppm}$ and $500 \mathrm{ppm}$ for the application of inoculated AMF with foliar-Fe.

\section{DISUSSION}

This study included two studied factors: two mycorrhizal treatments (inoculum AMF and native $\mathrm{AMF})$ and five foliar Fe concentrations (0.0, 300, 400, 500 and $600 \mathrm{ppm}$ ) and their interactions. Isolated AMF spores have been identified with the help of keys suggested by (Silva et al., 2005; Amutha and Shamini 2016; INVAM 2020). Our findings agree with many researchers who found that genus Glomus is a predominantly distributed genus in the soil all over the world (Abdulla and Al-Khaliel, 2010; Mansour, 2010 and Yaseen et al., 2016). Obtained results are in a good line with the findings of Nafady et al., (2018). The author reported that five morphotypes of AMF were belonging to three families (Aculosopraceae, Glomeraceae, and Gigasporaceae) were recovered from soil samples under study. AMF species were Acaulospora bireticulata, Acaulospora leavis, Glomus caesaris, Glomus clarum and Gigaspora margarita. The spore density found in this study was like that found by Teixeira et al., (2017) who showed that a total of 59 AMF species was distributed in 12 genera and seven families of Glomeromycota. Most of the species found (42\%) belong to the genus Acaulospora (13 species). Fernandes et al., (2016) found that a total of 42 AMF species were detected in four land uses. They reported that Acaulospora had the largest number of species (18), followed by Glomus (6) and Gigaspora (5), Gigaspora margarita and Gigaspora decipiens were present in all areas.

The inoculum potential of AMF in soil as spores have been increased by growing maize (Zea mays L.) as a recommended trap plant for a period of 4 months to increase spore density. These results were in harmony with those found by (Watson and Milner, 1996; Liu and Wang 2003; Yaseen et al., (2016). In addition, it is well known that trap cultures, using some crops such as maize, onion, grass and sorghum plants grown in soil diluted with sterile sand are most used to isolate $\mathrm{AMF}$ and the number of spores increased gradually from time such as increased from vegetative stage to fruiting stage. The trap culturing method usually results in the isolation of more species than other methods. Spore counts and total root colonization $(\%)$ in the soils under investigation showed great variability with inoculum $\mathrm{AMF}$ and native $\mathrm{AMF}$ at different concentrations of foliar Fe application. These results are in a line with (Rachid et al., 2013; de Araujo Pereira et al., 2017; Nafady et al., 2018 and Pereira et al., 2019). The authors found that dual inoculation of AMF significantly increased spore density and mycorrhizal colonization compared with single inoculation with AMF in faba bean plant. These results are in a line with Juntahum et al. (2020) who observed the number of spore changes with time, and the spore density is highest after 8 months. In the unfertilized and non-inoculated controls, the spore density was the lowest. In this respect, Sathiyadash et al. (2017) showed that AM fungal hyphal growth and root colonization are suppressed by high levels of micronutrients $(\mathrm{Cu}, \mathrm{Zn}, \mathrm{Mn}$, and $\mathrm{Fe})$ in soil. It is worthy to mention that the effect of inoculum with $\mathrm{AMF}$ and foliar Fe concentrations and their interaction on nodules formation of Rhizobium strain on broad bean roots are in agreement with many researchers (Dubova et al., 2015 and Pereira et al., 2019). The authors showed that applying Rhizobium laguerreae with or without AMF in legume crops significantly increased number of nodules/plant.

In addition, El-Tantawy and Nawar (2013) observed that inoculation of faba bean plants with or without $\mathrm{Fe}$ as foliar spray at $500 \mathrm{ppm}$ and inoculation with Rhizobium reflected significant interaction effect on number of active nodules/plant. The promotive effect of $\mathrm{Fe}$ on faba bean nodulation might be attributed to that $\mathrm{Fe}$ contributes in many of enzymatic activities, such as catalase, peroxidase, and nitrate reductase. Fe metabolism is of importance in nodules since this metal 
Table (7): Effect of Inoculum AMF, foliar iron (Fe) concentrations and their interaction on yield and its component of Vicia faba plant.

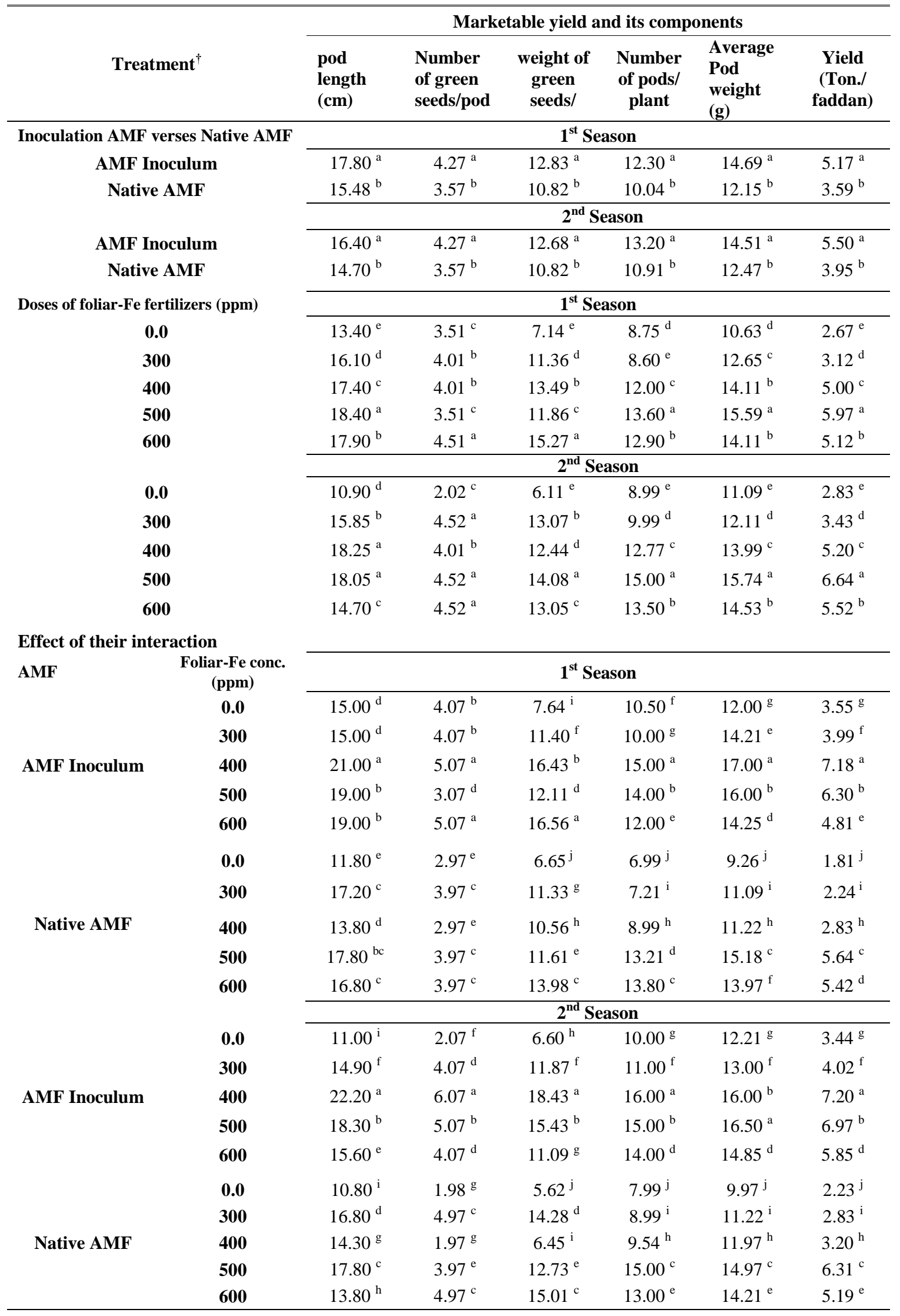

${ }^{\dagger}$ AMF Inoculum, propagated AMF isolated from different plants by trap culture and inoculated to broad bean; Native AMF, AMF exist in soil as native AMF, no inoculation. Means followed by the same (s) per column are not significantly different at $p \leq 0.05$ according to Duncan's multiple range test 
is a constituent of key proteins such as nitrogenase and leghemoglobin (Moreau et al., 1995). The increments in plant growth parameters due to application of inoculum with AMF might be attributed to the enhancing of nutrients uptake, increment in nitrogen fixation, phosphate solubilization and synthesis of phytohormones as reported by previous research work (Al-Karaki 2017; Sathiyadash et al. 2017; Pereira et al., 2019). These results might be due to Fe roles in contributing to other nutrients in increasing plant growth. According to Clark and Zeto (1996), levels of nutrients are low in alkaline soil (like the soil in the present study), mycorrhizae hyphae enhance Fe uptake. In this connection, Kobrace et al., (2011) reported that growth, photosynthesis pigments, nodulation and dry matter production were increased by adding $\mathrm{Fe}$. In addition, these results are in accordance with the findings of (El-Tantawy and Nawar 2013 and Houimli et al., 2015). The increment of plant growth due to the combination of inoculum with AMF and foliar $\mathrm{Fe}$ application at $500 \mathrm{ppm}$ might be owed to the vital roles of AMF on releasing phosphates for plants, nitrogen fixation, alleviating soil stress, improving soil structure through a network hypha as reported by (Abdel Latef and Chaoxing 2011; Porcel et al., 2012 and Abd-Alla et al., 2014)

Additionally, the vital roles of $\mathrm{Fe}$ on nodulation and consequently achievement in nitrogen fixation, its roles in heam and non heam enzymes, as a component of photosynthetic pigments as well as in photo assimilation process that was reflected on broad bean plant growth. Furthermore, the obtained results are coinciding with those reported by many researchers (Oliveira et al., 2017; Fouda and Abd-Elhamied, 2017; Nafady et al., 2018; Pereira et al., 2019). Finally, AbdAlla et al., (2014) found increases in dry matter accumulation of shoots and roots of faba bean which inoculated with AMF and $R$. leguminosarum in alkaline soil. In this direction, Khatun (2020) indicated that AMF inoculation significantly increases all the growth parameters such as height of the plants, length of the roots, fresh weight of shoot, roots, tubers of Coleus plants than the control. In addition, Elkhatib et $a l$. , (2008) found that mycorrhizal inoculation plants gave higher yield fed $^{-1}$ than those inoculated with phosphorein. Also, the increments in yield and its components might be owed to the increment in active nodules formation, increasing in photosynthetic pigments, dry weight of plant and therefore increasing in yield. Srivastava and Gupta (1996) reported that Fe present in heam containing enzymes and in non heam compounds; i.e., peroxidase, catalase, cytochrome oxidase, ferodoxin and nitrate reductase. Nour (2004) found that spraying pea plants with $\mathrm{Fe}$ increased number of active nodules/plant, nitrogenase activity, seeds weight /pod, yield/plant and shelling out (\%). Also, El-Tantawy and Nawar (2013) found that faba bean plants sprayed with $\mathrm{Fe}$ scored significantly the highest total yield (kg/faddan) compared to control treatment. According to our results the effect of interaction between inoculated $\mathrm{AMF}$ and foliar $\mathrm{Fe}$ concentrations agree with those reported by (Veselaj et al., 2018 and Pereira et al., 2019) who showed that the inoculation with AMF improved productivity parameters such as number of pods and weight of pods and seeds, so that increased yield significantly. Also, this result found by Juntahum et al., (2020) who showed an increased productivity in Sugarcane plant by inoculation AMF alone while, the highest plant biomass and productivity were observed in the $\mathrm{AMF}{ }^{+}$ $50 \% \mathrm{P}$ treatment.

\section{CONCLUSION}

AMF in an agricultural ecosystem is required for good management of the beneficial symbiosis. At the end of this study, it brings to light the importance of inoculation of Vicia faba plants with AMF and application of foliar-Fe which generally increased all measured parameters (AMF spore counts, root colonization $\%$, nodule formation, improved the overall plant biomass, chlorophyll content and plant yield as compared with control plants without any treatment). The proposed combined approach of the current work emphasized the utilization of foliar-Fe, at dose 400-500 ppm, and inoculation of legumes with AMF as an alternative step towards the establishment of cost effective and eco-friendly preparation of sustainable biofertilizer. The combination between inoculum AMF and foliar-Fe could increase the efficiency and commercialization of environmental friendly biofertilizer application in agriculture cropping systems.

\section{REFERENCES}

ABD-ALLA, M., A.W.E. EL-ENANY, N.A. NAFADY, D.M. KHALAF AND F.M. MORSY. 2014. Synergistic interaction of Rhizobium leguminosarum bv. viciae and arbuscular mycorrhizal fungi as a plant growth promoting biofertilizers for faba bean (Vicia faba L.) in alkaline soil. Microbiology Research 169, 49-58.

ABDEL LATEF, A.A.H. AND H. CHAOXING. 2011. Effect of arbuscular mycorrhizal fungi on growth, mineral nutrition, antioxidant enzymes activity and fruit yield of tomato grown under salinity stress. Sci. Hortic., 127, 228-233.

ABDULLA, S. AND AL-KHALIEL. 2010. Effects of Arbuscular Mycorrhization in sterile and non-sterile soils. Tropical Life Sciences Research 21(1):55-72.

AL JANABI, H.Y.A. 2016. Effect of irrigation water salinity and iron fertilizers on soil salinity, growth and yield of Cucurbita pepo (L.). Adv. Life Sci. Technol. 45, 13-21.

AL-KARAKI, G.N. 2017. Effects of Mycorrhizal Fungi Inoculation on Green Pepper Yield and Mineral Uptake under Irrigation with Saline Water. Adv. Plants Agric. Res., 6, 00231.

AMUTHA, K. AND S. SHAMINI 2016. Studies on diversity of arbuscular mycorrhizal fungi in Tamil Nadu. Eco. Enu. \& Cons. 22(4): pp.1823-1828.

BAREA, J.M. AND P. JEFFRIES. 1995. Arbuscular 
mycorrhizas in sustainable soil plant systems. In: Varma A. and B. Hock (eds.). Mycorrhiza: structure, function, molecular biology and biotechnology. Springer-Verlag, Berlin. 521-560.

BONFANTE, P. AND A. GENRE 2008. Plants and arbuscular mycorrhizal fungi: an evolutionarydevelopmental perspective. Trends Plant Sci. 13:492-498.

CLARK, R.B. AND S.K. ZETO. 1996. Iron acquisition by mycorrhizal maize grown on alkaline soil. J. Plant Nutr.; 19: 247-264.

De Araujo Pereira, A.P., P.A.M. DE Andrade, D. Bini, A. Durrer, A. Robin, J.P Bouillet And E.J.B.N. Cardoso. 2017. Shifts in the bacterial community composition along deep soil profiles in monospecific and mixed stands of Eucalyptus grandis and Acacia mangium. PloS one, 12(7).

DORNELESS, M. R., C. M DA SILVA AND A. A. GOMES, 2001. A model for hyphae effects in phosphorus absorption by plants. Ecological Modeling, 142: 83-89.

DUBOVA, I., A. ŠENBERGA AND I. ALSINA. 2015. The effect of double inoculation on the broad beans (Vicia faba L.) yield quality. Research for Rural Development 1, 34-39.

DUNCAN, D.B., 1958. Multiple range and multiple F. Test. Biometrics, 11: 1-42

ELKHATIB, H.A., S.M. Gabr, F.I. RADWAN and R.F. ABO EL-ALI 2008. A Comparative study of Arbuscular mycorrhizal fungi, phosphate solubilizing Bacteria and phosphate fertilizer effects on growth, yield and mineral contents of common Bean (Phaseolus Vulgaris L.). Alexandria science exchange journal, 29(3).

EL-MANSI, A.A., H.M. ARISHA, A.I. EL-KASSAS AND E.M.E NOUR. 2005. Effect of iron, molybdenum and boron and their application methods on pea plants under sandy soil conditions. I. Morphological characters, photosynthetic pigments, dry weight and enzymes activity. The 6th Arabia Conference for Horticulture, Ismailia, Egypt, 325-339.

EL-TANTAWY, E.M. AND DALIA A. S. NAWAR. 2013. Nodulation, Growth, Photosynthetic Pigments and Yield of Broad Bean Plants (Vicia faba L.) as Affected by Nitrogen Source, Rhizobium Inoculation and iron foliar Application. Journal of Applied Sciences Research, 9(1): 974987.

FEDDERMANN, N, R. FINLAY, T. BOLLER AND M. ELFSTRAND. 2010. Functional diversity in arbuscular mycorrhiza - the role of gene expression, phosphorous nutrition and symbiotic efficiency. Fungal Ecol. 3: 1-8.

FERHI, J., M. GHARSALLI, C. ABDELLY, AND A. KROUMA 2017. Potential of the physiological response of pea plants (Pisum sativum L.) to iron deficiency (direct or lime- induced). Bioscience Journal,33(5):1208-1218.

FERNANDES, R.A, D.A. FERREIRA, O.J. SAGGINJUNIOR, S.L. STÜRMER, H.B. PAULINO, J.O.
SIQUEIRA AND M.A.C. CARNEIRO. 2016. Occurrence and species richness of mycorrhizal fungi in soil under different land use. Canadian Journal of Soil Science, 96(3):271-280.

FOUDA, K. F. AND A. S. ABD-ELHAMIED. 2017. Integrated Effect of Foliar Fertilization of Fe, $\mathrm{Zn}$ and Rates of Fertilization on Growth and Yield of Cowpea. J. Soil Sci. and Agric. Eng., Mansoura Univ.,8 (12): 733 - 740.

GAO, LI, AND Y. SHI. 2007. Genetic differences in resistance to iron deficiency chlorosis in peanut. $\mathbf{J}$. Plant Nutr. 30: 37 - 52.

GARMENDIA, I, N. GOICOECHEA AND J. AGUIRREOLEA. 2004. Effectiveness of three Glomus species in protecting pepper (Capsicum annuum L.) against Verticillium wilt. Biol. Control 31(3):296-305.

GERDEMANN, J.W. AND J.M. TRAPPE. 1974. The Endogonaceae in the pacific Northwest. Mycologia Mem.,5: 1-76.

GERDEMANN, J.W. AND T.H. NICOLSON. 1963. Spores of mycorrhizal Endogone species extracted from soil by wet-sieving and decanting. Transactions of the British Mycological Society.46: 235-244.

GHEDA, S.F. AND D.A. AHMED, 2015. Improved soil characteristics and wheat germination as influenced by inoculation of Nostoc kihlmani and Anabaena cylindrica. Rend Lincei Sci Fis Nat. 26(2), 121-131.

GIOVANNETTI, M. AND B. MOSSE. 1980. An evaluation of techniques for measuring vesicular arbuscular mycorrhizal infection in roots. New Phytol., 84:489-500.

HEIDARIAN, A.R., H. KORD, M. KHODADAD, A.P. LAK AND F.A. MASHHADI. 2011. Investigating $\mathrm{Fe}$ and $\mathrm{Zn}$ foliar application on yield and its components of soybean (Glycine max (L) Merr.) at different growth stages. J. Agric. Biotech. Sustainable Dev., 3(9): 189 -197.

HOUIMLI, S.I.M., H. JDIDI, F. BOUJELBEN AND M. DENDEN 2015. Improvement of tomato (lycopersicon esculentum 1.) productivity in calcareous soil by iron foliar application. International Journal of Advanced Research, 3(9):1118- 11231118.

HOUIMLI, S.I.M., H. JDIDI, F. BOUJELBEN AND M. DENDEN. 2016. Fruit yield and quality of ironsprayed tomato (Lycopersicon esculentum Mill.) grown on high $\mathrm{pH}$ calcareous soil. IJISR, 20(2), 268-271.

HUBBELL, D.H. AND K. GERALD, 2003. Biological nitrogen fixation. Fact sheet of the soil and water science department of food and agricultural sciences, University of Florida, pp: 4.

INVAM. 2020. International Culture Collection of (Vesicular) Arbuscular Mycorrhizal Fung.[cited 2020]. Available from: https://invam.wvu.edu/.

JACKSON, M. L. 1958. Soil Chemical Analysis. Prentice hall Inc. Englewood Cliffs, N.J., U.S.A. 
JUNTAHUM S., JONGRUNGKLANG, N., WANWIPA KAEWPRADIT, W., LUMYONG, S. AND BOONLUE, S. 2020. Impact of Arbuscular Mycorrhizal Fungi on Growth and Productivity of Sugarcane Under Field Conditions. Sugar Tech, 22(3):451-459.

KHATUN S. 2020. Effect of Glomus fasciculatum On Nutrient Uptake and Growth of a Medicinal Plant, Coleus forskohlii. European Journal of Medicinal Plants,31(4): 25-37

KOBRACE, S., N.M. NOOR, S.H. HEIDARI, K.F. DARVISH AND B. DELKHOSH. 2011. Influence of micronutrient fertilizer on soybean nutrient composition. Indian J. Sci. Technol., 4(7). 332-349.

KUMAR, A., J.F. DAMES, A. GUPTA, S. SHARMA, J.A. GILBERT AND P. AHMAD. 2014. Current developments in arbuscular mycorrhizal fungi research and its role in salinity stress alleviation: A biotechnological perspective. Crit. Rev. Biotechnol., 8551, 1-14.

LIU, R. AND F. WANG. 2003. Selection of appropriate host plants used in trap culture of arbuscular mycorrhizal fungi. Mycorrhiza, 13:123127.

MANN, A., A. L. SINGH, S. OZA, N. GOSWAMI, D. MEHTA AND V. CHAUDHARI. 2017. Effect of iron source on iron deficiency induced chlorosis in groundnut. Legume Research, 40(2): 241-249.

MANSOUR, M.A.I. 2010. Endomycorrhizal fungi as a biocontrol mean of tomato-fusarial-wilt in North Sinai. Faculty of Science, Suez Canal University, Ismailia, Egypt.

MARSCHNER, H. 2002. Mineral nutrition of higher plants. Academic Press, London. 889 p.

MCGONIGLE, T.P., M. H. MILLER, D. G. EVANS, G. L. FAIRCHILD AND J. A. SWAN. 1990. A new method, which gives an objective measure of colonization of roots by vesicular-arbuscular mycorrhizal fungi. New Phytologist 15:490-501

MENGE, J.A. AND L.W. TIMMER. 1982. Procedure for inoculation of plants with vesicular arbuscular mycorrhizae in the laboratory. Green house and field. In: Methods and principles of mycorrhizal research, St. Paul: American Phytopathol. Soc., 59.

MOREAU, S., J. MEYER AND A. PUPPO. 1995. Uptake of iron by symbiosomes and bacteroids from soybean nodules. FEBS Letters, 361: 225-228.

NAFADY, N. A., E. A. HASSAN, M. H. ABD-ALLA AND M. M. K. BAGY. 2018. Effectiveness of ecofriendly arbuscular mycorrhizal fungi biofertilizer and bacterial feather hydrolysate in promoting growth of Vicia faba in sandy soil. Biocatalysis and Agricultural Biotechnology, 16, 140-147.

NATALIA, GUTIERREZ C., M.T. MORENO AND A.M. TORRES. 2008. Development of SCAR markers linked to zt-2, one of the gens. Controlling adsence of tannins in faba bean. Aust J. of Agric. Res. 59: 6-68.

NGAKOU, A., C. MEGUENI, H. OUSSENI AND A. MASSAI, 2009. Study on the isolation and characterization of rhizobia strains as biofertilizer tools for growth improvement of four grain legumes in Ngaoundéré-Cameroon. Int. J. Biol. Chem. Sci., 3: 1078-1089

NOUR, E.M.E. 2004. Physiological studies on pea crop under sandy soil conditions. Ph. D. Thesis, Hort. Dept., Fac. Agric. Zagazig university.

O'ROURKE, J.A., Y.T. BOLON, B. BUCCIARELLI AND C.P. VANCE. 2014. Legume genomics: Understanding biology through DNA and RNA sequencing. Annals of Botany, 113(7),1107-1120.

OLIVEIRA, R.S., P. CARVALHO, G. MARQUES, L. FERREIRA, S. PEREIRA, M. NUNES, I. ROCHA, Y. MA, M.F. CARVALHO, M. VOSÁTKA AND H. FREITAS. 2017. Improved grain yield of cowpea (Vigna unguiculata) under water deficit after inoculation with Bradyrhizobium elkanii and Rhizophagus irregularis. Crop \& Pasture Science 68, 1052-1059.

PEREIRA, S., A. MUCHA, B. GONCALVES, E. BACELAR, A. LÁTR, H. FERREIRA, I. OLIVEIRA, E. ROSA, AND G. MARQUES. 2019. Improvement of some growth and yield parameters of faba bean (Vicia faba) by inoculation with Rhizobium laguerreae and arbuscular mycorrhizal fungi. Crop \& Pasture Science, 70, 595-605.

PIPER, C. S. 1947. Soil and Plant Analysis. The University of Adelaide (Australia): 59-74.

PORCEL, R., R. AROCA AND J.M. RUIZ-LOZANO. 2012. Salinity stress alleviation using arbuscular mycorrhizal fungi. A review Agron. Sustain.32, 181-200.

POZO, MJ, C. CORDIER, E. DUMAS-GAUDOT, S. GIANINAZZI, JM. BAREA AND C. AZCÓNAGUILAR. 2002. Localized versus systemic effect of arbuscular mycorrhizal fungi on defence responses to Phytophthora infection in tomato plants. J. Exp. Bot. 53(368):525-534.

RACHID, C.T.C.C., F.C. BALIEIRO, R.S. PEIXOTO, Y.A.S. PINHEIRO, PICCOLO, G.M. CHAER AND A.S. ROSADO. 2013. Mixed plantations can promote microbial integration and soil nitrate increases with changes in the $\mathrm{N}$ cycling genes. Soil Biology and Biochemistry., 66; 146-153.

RAVOLANIRINA, F., V. GIANINAZZI-PEARSON AND S. GIANINAZZI. 1987. Preliminary studies in vitro endomycorrhizal inoculation of micropropagated tree species of nutritional value, In: FSP. Trees and mycorrhizae. Proc. Asian Seminar, 91-101.

REN, L., F. ELLER, C. LAMBERTINI, W. GUO, B.K. SORRELL, AND H. BRIX. 2017. Minimum $\mathrm{Fe}$ requirement and toxic tissue concentration of $\mathrm{Fe}$ in Phragmites australis: A tool for alleviating Fedeficiency in constructed wetlands. Ecological Engineering, 118: 152-160.

ROUT, G.R. AND S. SAHOO 2015. Role of iron in plant growth and metabolism. Reviews in Agricultural Science. 3:1- 24.

SALAMA, F.M., EL-GHANI, M.M.A., EL-TAYEH, N.A., AMRO, A., ABDRABBU, H.S., 2017. Correlations between soil variables and weed communities in major crops of the desert reclaimed 
lands in southern Egypt. Rend Lincei Sci Fis Nat. $28,363-378$.

SATHIYADASH, K., K. RAJENDRAN, V. KARTHIKEYAN, AND T. MUTHUKUMAR. 2017. Modulation of plant micronutrient uptake by arbuscular mycorrhizal fungi. Probiotics and Plant Health, DOI 10.1007/978-981-10-3473-2-14

SEPETOGLU, H., 2002. Grain legumes. Ege Univ. Fac. Agric. Publication: 24/4. 262.

SILVA, G.A., C.M. LEONOR AND L.S. SIDNEY. 2005. A dichotomous key to Scutellospora species (Gigasporaceae, Glomeromycota) using morphological characters. Mycotaxon, 94: 293-301.

SMITH, S.E., E. FACELLI, S. POPE AND F.A. SMITH. 2010. Plant performance in stressful environments: interpreting new and established knowledge of the roles of arbuscular mycorrhizas. Plant and Soil 3(26):3-20.

SNEDECOR, G.W. AND W.G. COCHRAN. 1980. Statistical Methods 7th ed. Iowa State Univ. Press. Ames. Iowa, USA.

SOMASEGARAN, P. AND H.J. HOBEN 1985. Methods in legume-Rhizobium technology. Hawaii, USA: Hawaii Institute of Tropical Agriculture and Human Resources.

SRIVASTAVA, P.C. AND U. C. GUPTA. 1996. Trace Elements in Crop Production. Science Pub. Inc. Lebanon, NH 03766 USA, 366pp.

TANTAWY, A.S., Y.A.M. SALAMA, A.M.R. ABDEL MAWGOUD AND M.F. ZAKI 2013. Interaction of $\mathrm{Fe}$ and salinity on growth and production of tomato plants. World Appl. Sci. J., 27(5): 597-609.

TEIXEIRA, A.F.S., K. KEMMELMEIER, M.N. MARASCALCHI, S.L. STÜRMER, M.A.C. CARNEIRO AND F.M.S. MOREIRA. 2017. Arbuscular mycorrhizal fungal communities in an iron mining area and its surroundings: Inoculum potential, density, and diversity of spores related to soil properties. Ciência e Agrotecnologia, 41(5):511-525.

TROUVELOT, A., J.L. KOUGH AND V. GIANINAZZI-PEARSON. 1986. Mesure du taux de mycorhization VA d’un systéme radiculaire. Recherche de méthodes d’estimation ayant une signification fonctionnelle. In Physiological and Genetical Aspects of Mycorrhizae, GianinazziPearson V, Gianinazzi S eds, 217-221.

VESELAJ, E., G. SALLAKU AND A. BALLIU. 2018. Tripartite relationships in legume crops are Plantmicroorganism-specific and strongly influenced by salinity. Agriculture, 8, 117; doi:10.3390/agriculture8080117.

WANG, CX, X.L. LI, F.Q. SONG, G.Q. WANG AND B.Q. LI. 2012. Effects of arbuscular mycorrhizal fungi on Fusarium wilt and disease resistancerelated enzyme activity in cucumber seedling root. Chin J Eco-Agric., 20(1):53-57.

WATSON, D.M.H AND P.D. MILNER. 1996. Assessment of glomalean species biodiversity as influenced by trapping methods. In: Szaro TM, Bruns TD (eds). Programs and Abstracts of the First International Conference on Mycorrhizae. University of California, Berkeley, Calif. p 125.

WETTESTEIN, D. 1957. Chlorophyll- lethale under submichoroscophic fromwechsel der Plastiden. Exptl. Cell. Res., 12: 427-500.

YASEEN, T., F. HUSSAIN AND M. SHAKEEL. 2016. Effect of Rhizobium, VAM and rock phosphate inoculation on growth and productivity and isolation of VAM spores of Pisum sativum. Pure and Applied Biology., 5(3): 564-572.

ZARGHAMNEJAD, Z., K.P. KORDLAGHARI ANDK. KESHAVARZI 2015. Efficacy of foliar application of ferrous and manganese sulfate on wet and dry biomass of tomato (Lycopersicon esculentum) in greenhouse. International Journal of Biosciences. 6: 437- 444. 


\title{
التأثثر المشترك للتلقيح بفطريات الميكوريزا الداخلية والتسميد الورقي بالحديد على نمو و إنتاجية نبات الفول تحت ظروف شمال سيناء
}

\author{
أحمد بلال المنسي1، محمد أحمد إبراهيم منصور2، محمود إبراهيم محمود 1

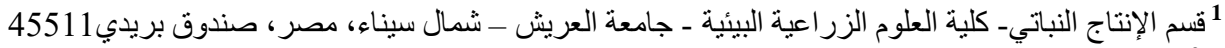

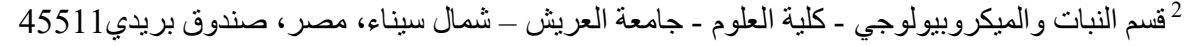 \\ الملخص العربي
}

أُجريت هذه الدراسة في المزرعة التجريبية لكلية العلوم الزر اعية البيئية، جامعة العريش، محافظة شمال سيناء، جمهورية مصر العربية،

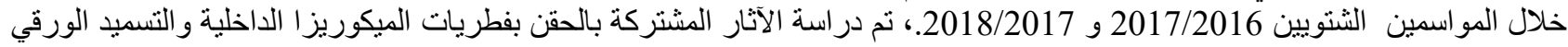

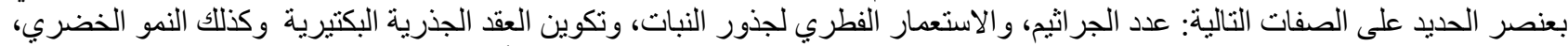

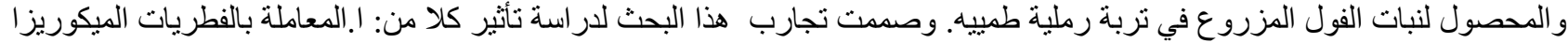

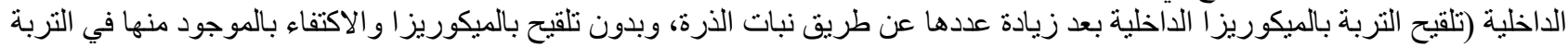

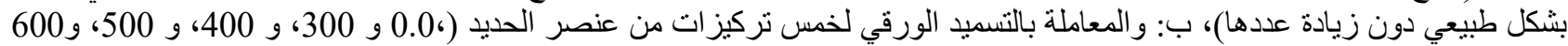

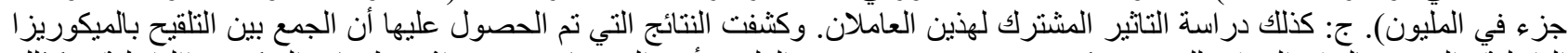

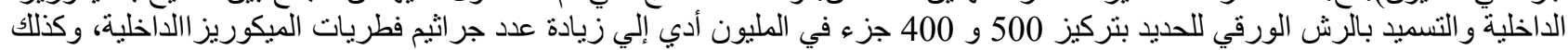

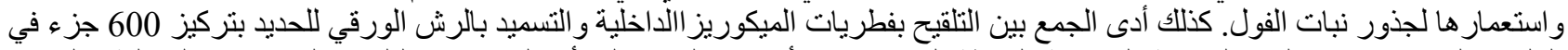

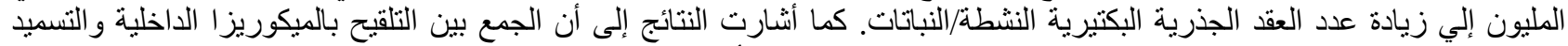

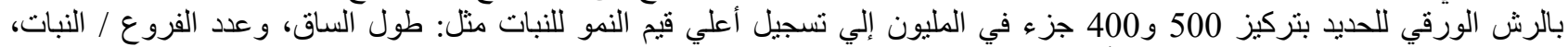

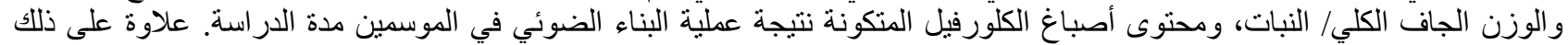

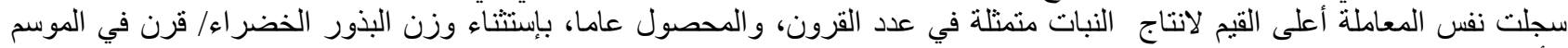
الأول، ومتوسطوزن القطرن القلى (جم) في الموسم الثناني. 